\title{
Correction: A fibrin/hyaluronic acid hydrogel for the delivery of mesenchymal stem cells and potential for articular cartilage repair
}

Timothy N Snyder ${ }^{1,2 \dagger}$, Krishna Madhavan $^{1 \dagger}{ }^{,}$Miranda Intrator ${ }^{1}$, Ryan C Dregalla ${ }^{2}$ and Daewon Park ${ }^{1 *}$

The authors would like to add the following detail to the Competing Interests and Acknowledgments stated in the published article [1] "At the time of writing, TNS and RCD were employees of Regenerative Sciences, LLC. The authors also would like to especially thank Dr. Christopher Centeno and Regenerative Sciences for partially supporting and funding this project."

Received: 28 October 2014 Accepted: 28 October 2014

Published: 28 November 2014

\section{Reference}

1. Snyder TN, Madhavan K, Intrator M, Dregalla RC, Park D: A fibrin/hyaluronic acid hydrogel for the delivery of mesenchymal stem cells and potential for articular cartilage repair. J Biol Eng. 2014, 8:10.

\footnotetext{
* Correspondence: daewon.park@ucdenver.edu

†Equal contributors

${ }^{1}$ Bioengineering Department, University of Colorado, Anschutz Medical Campus, Mail Stop 8607, 12700 East 19th Avenue, Aurora, CO 80045, USA

${ }^{2}$ Regenerative Sciences, 403 Summit Blvd, Suite 201, Broomfield, CO 80021 , USA
}

\section{Submit your next manuscript to BioMed Central and take full advantage of:}

- Convenient online submission

- Thorough peer review

- No space constraints or color figure charges

- Immediate publication on acceptance

- Inclusion in PubMed, CAS, Scopus and Google Scholar

- Research which is freely available for redistribution

Submit your manuscript at www.biomedcentral.com/submit 